Author manuscript

NanoImpact. Author manuscript; available in PMC 2019 July 01.

About author manuscripts

Submit a manuscript

Published in final edited form as:

NanoImpact. 2018 July ; 11: 156-163. doi:10.1016/j.impact.2018.08.003.

\title{
Shifts in $\mathrm{N}$ and $\delta^{15} \mathrm{~N}$ in wheat and barley exposed to cerium oxide nanoparticles
}

\author{
Cyren M. Rico ${ }^{a, b, d,{ }^{*}, \dagger}$, Mark G. Johnson ${ }^{b}$, Matthew A. Marcus ${ }^{c}$, and Christian P. Andersen ${ }^{b}$ \\ aNational Research Council, Research Associateship Program, 500 Fifth Street, NW, \\ Washington, DC 20001, USA \\ bUS Environmental Protection Agency, National Health and Environmental Effects Research \\ Laboratory, Western Ecology Division, 200 SW 35th St., Corvallis, OR 97333, USA \\ 'Advanced Light Source, Lawrence Berkeley National Laboratory, 1 Cyclotron Road, Berkeley, CA \\ 94720, USA \\ dMissouri State University, Department of Chemistry, 901 S National Ave., Springfield, MO 65897, \\ USA
}

\begin{abstract}
The effects of cerium oxide nanoparticles $\left(\mathrm{CeO}_{2}-\mathrm{NPs}\right)$ on ${ }^{15} \mathrm{~N} /{ }^{14} \mathrm{~N}$ ratio $\left(\delta^{15} \mathrm{~N}\right)$ in wheat and barley were investigated. Seedlings were exposed to 0 and $500 \mathrm{mg} \mathrm{CeO}{ }_{2}-\mathrm{NPs} / \mathrm{L}$ (Ce-0 and Ce-500, respectively) in hydroponic suspension supplied with $\mathrm{NH}_{4} \mathrm{NO}_{3}, \mathrm{NH}_{4}{ }^{+}$, or $\mathrm{NO}_{3}{ }^{-}$. $\mathrm{N}$ uptake and $\delta^{15} \mathrm{~N}$ discrimination (i.e. differences in $\delta^{15} \mathrm{~N}$ of plant and $\delta^{15} \mathrm{~N}$ of $\mathrm{N}$ source) were measured. Results showed that $\mathrm{N}$ content and ${ }^{15} \mathrm{~N}$ abundance decreased in wheat but increased in barley. Ce-500 only induced whole-plant $\delta^{15} \mathrm{~N}$ discrimination $(-1.48 \%, \mathrm{P} \leq 0.10)$ with a simultaneous decrease $(\mathrm{P} \leq 0.05)$ in whole-plant $\delta^{15} \mathrm{~N}\left(-3.24 \%\right.$ ) compared to Ce- $0\left(-2.74 \%\right.$ ) in wheat in $\mathrm{NH}_{4}{ }^{+}$. Ce-500 decreased $(\mathrm{P} \leq 0.01)$ root $\delta^{15} \mathrm{~N}$ of wheat in $\mathrm{NH}_{4} \mathrm{NO}_{3}$ and $\mathrm{NH}_{4}{ }^{+}(3.23$ and $-2.25 \%$, respectively) compared to Ce-0 (4.96 and $-1.27 \%$, respectively), but increased ( $\mathrm{P} \leq 0.05)$ root $\delta^{15} \mathrm{~N}$ of wheat in $\mathrm{NO}_{3}{ }^{-}(3.27 \%$ ) compared to $\mathrm{Ce}-0(2.60 \%)$. Synchrotron micro-XRF revealed the presence of $\mathrm{CeO}_{2}-\mathrm{NPs}$ in shoots of wheat and barley regardless of $\mathrm{N}$ source. Although the longerterm consequences of $\mathrm{CeO}_{2}-\mathrm{NP}$ exposure on $\mathrm{N}$ uptake and metabolism are unknown, the results clearly show the potential for ENMs to interfere with plant metabolism of critical plant nutrients such as $\mathrm{N}$ even when toxicity is not observed.
\end{abstract}

\section{Keywords}

environmental engineered nanomaterial; isotope; nitrogen; synchrotron micro-XRF

\footnotetext{
*Corresponding author. Tel: 417836 3304; Fax: 417836 5507; CyrenRico@ MissouriState.edu (C. M. Rico).

${ }^{\dagger}$ This research project was started at US EPA and finished at Missouri State University. The experimental part and $\mathrm{N}$ and $\delta^{15} \mathrm{~N}$ analysis were performed at US EPA while synchrotron analysis was performed when the first author moved to Missouri State University.
} 


\section{Introduction}

Engineered nanomaterials (ENMs) are being used in a wide array of consumer products. The vast majority of ENM studies have examined the acute toxicity of nanoparticles and particle forms to determine if they represent a risk to human health and/or the environment (Servin and White, 2016; Zuverza-Mena et al., 2017). In studies that examined the effects of metal oxide nanoparticles on plants, most studies have shown low to moderate toxicity, even at relatively high ENM concentrations (Servin and White, 2016). However, release of ENMs into the environment may have other subtle effects on plant uptake and use of important nutrients, which could alter growth and development. For example, nitrogen is one of the most important nutrients since it is an essential component of amino acids, proteins and nucleic acids, including the carboxylating enzyme involved in photosynthesis (Tamm, 1991). Although many forms of $\mathrm{N}$ occur in soils, not all forms are available to plants. In addition, microbial processing of $\mathrm{N}$ affects pools and fluxes of $\mathrm{N}$ in soils. Understanding the effects of ENMs on factors such as $\mathrm{N}$ uptake and metabolism is important not only to understand plant growth and development, but also for understanding how ENMs may affect ecosystem processes.

Different isotopes of $\mathrm{N}$ have been used as sensitive indicators of metabolic change and also reflect shifts in ecosystem processing of $\mathrm{N}$ (Banas et al., 2009; Marshall et al., 2007). The ${ }^{15} \mathrm{~N} /{ }^{14} \mathrm{~N}$ ratio of plant tissue can be used to follow changes in response to both natural and environmental stresses, and often reflects discrimination against the heavier ${ }^{15} \mathrm{~N}$ isotope compared to the lighter ${ }^{14} \mathrm{~N}$ isotope (Craine et al., 2015; Kalcsits et al., 2014; Unkovich, 2013). Isotopic composition $\left(\delta^{15} N\right)$ is expressed as

$$
\delta^{15} N(\% 0)=\left(\frac{R_{\text {sample }}}{R_{\text {standard }}}-1\right) \times 1000
$$

where $R_{\text {sample }}$ is the ${ }^{15} \mathrm{~N} /{ }^{14} \mathrm{~N}$ ratio of the sample and $R_{\text {standard }}$ is the ratio of known standard. The standard for nitrogen is atmospheric nitrogen $\left({ }^{15} \mathrm{~N} /{ }^{14} \mathrm{~N}=0.0036765\right)$ (Craine et al., 2015; Kalcsits et al., 2014; Unkovich, 2013). Nitrogen isotope discrimination occurs when ${ }^{14} \mathrm{~N}$ is utilized more readily than ${ }^{15} \mathrm{~N}$, resulting in lower and more negative $\delta^{15} \mathrm{~N}$ of plants $\left(\delta^{15} \mathrm{~N}_{\mathrm{p}}\right)$ than $\delta^{15} \mathrm{~N}$ of inorganic $\mathrm{N}$ source $\left(\delta^{15} \mathrm{~N}_{\mathrm{s}}\right)$. Figure A.1 summarizes nitrogen isotope discrimination in plants (Evans et al., 1996, 2001; Kalcsits et al., 2014; Kalcsits and Guy, 2013; Mariotti et al., 1982). According to this model, isotope discrimination is a function of influx of $(\mathrm{N})_{\text {inorg }}$ from $\mathrm{N}$ source, assimilation by root enzymes (i.e. nitrate reductase and glutamine synthetase) yielding ${ }^{15} \mathrm{~N}$-enriched $(\mathrm{N})_{\text {inorg }}$ and ${ }^{15} \mathrm{~N}$-depleted $(\mathrm{N})_{\text {org }}$, efflux of unassimilated ${ }^{15} \mathrm{~N}$-enriched $(\mathrm{N})_{\text {inorg }}$, and xylem transport of $(\mathrm{N})_{\text {inorg }}$ to the shoots (Evans et al., 1996, 2001; Kalcsits et al., 2014; Kalcsits and Guy, 2013; Mariotti et al., 1982).

Kalcsits et al. (2014) also noted that nitrogen isotope discrimination is largely a function of supply of root $(\mathrm{N})_{\text {inorg }}$ relative to the plant's demand for $(\mathrm{N})_{\text {org }}$. When there is no loss of root $(\mathrm{N})_{\text {inorg }}$ prior to assimilation, discrimination will not occur because the entire root $(\mathrm{N})_{\text {inorg }}$ will be converted to $(\mathrm{N})_{\text {org }}$. Whole-plant $\delta^{15} \mathrm{~N}$ discrimination (i.e. differences between $\delta^{15} \mathrm{~N}_{\mathrm{p}}$ and $\delta^{15} \mathrm{~N}_{\mathrm{s}}$ ) occurs if fractionation occurs during influx or efflux occurs from unassimilated ${ }^{15} \mathrm{~N}$-enriched $(\mathrm{N})_{\text {inorg. }}$. Organ-level discrimination (i.e. difference between root and shoot 
$\delta^{15} \mathrm{~N}$ and $\delta^{15} \mathrm{~N}_{\mathrm{s}}$ ) is mainly the function of efflux of root $(\mathrm{N})_{\text {inorg }}$, and xylem transport of $(\mathrm{N})_{\text {inorg }}$ and ${ }^{15} \mathrm{~N}$-depleted $(\mathrm{N})_{\text {org }}$ to the shoots (Evans et al., 2001; Kalcsits et al., 2013, 2014).

Previous studies showed the impacts of heavy metal on $\mathrm{N}$ metabolism in plants, and it is possible that metal oxide nanoparticles could influence $N$ uptake. Sutter et al. (2012) reported that $\mathrm{Cd}, \mathrm{Pb}$, and $\mathrm{Zn}$ decreased ${ }^{15} \mathrm{~N}$ abundance in aquatic moss (Fontinalis antipyretica L. ex Hedw.) while Schmidt et al. (2004) found that As(III) or As(V) significantly decreased ${ }^{15} \mathrm{~N}$ incorporation in Silene vulgaris. These researchers found that metals affected $\mathrm{N}$ uptake and protein synthesis which resulted in decreased metabolic activity of plants. We also reported decreases in ${ }^{15} \mathrm{~N} /{ }^{14} \mathrm{~N}$ ratio of wheat treated with cerium oxide nanoparticles $\left(\mathrm{CeO}_{2}-\mathrm{NPs}\right)$, but did not find whether the isotopic changes occurred in the soil, the root rhizosphere, or after $\mathrm{N}$ uptake through changes in root or shoot metabolism (Rico et al., 2017).

In order to help isolate the mechanisms underlying changes in $\mathrm{N}$ uptake and/or metabolism in response to ENM exposure, we used hydroponic systems to allow us to control the forms and isotopic ratios of $\mathrm{N}$ supplied to the roots, and to minimize the influence of soil interactions external to plant roots. We selected $\mathrm{CeO}_{2}-\mathrm{NPs}$ since they are widely used in many technological applications that could reach the environment and interact with terrestrial/agricultural plant species (Dahle and Arai, 2015). In this study, the influence of $\mathrm{CeO}_{2}$-NPs on nitrogen metabolism of different forms of $\mathrm{N}$ (i.e. $\mathrm{NH}_{4} \mathrm{NO}_{3}, \mathrm{NH}_{4}{ }^{+}, \mathrm{NO}_{3}{ }^{-}$) in wheat (Triticum aestivum L.) and barley (Hordeum vulgare L.) was explored. The hypotheses were 1) $\mathrm{CeO}_{2}$-NPs do not alter uptake of $\mathrm{N}$ or growth in wheat and barley regardless of the form of $\mathrm{N}$ supplied, i.e., $\mathrm{NO}_{3}{ }^{-}, \mathrm{NH}_{4}{ }^{+}$or $\mathrm{NH}_{4} \mathrm{NO}_{3}, 2$ ) shifts in the isotopic ratios of $\mathrm{N}$ in leaves and roots in response to the different forms of $\mathrm{N}$ supplied are not influenced by $\mathrm{CeO}_{2}$-NPs exposure, and 3) wheat and barley show similar isotopic ratios in response to the different $\mathrm{N}$ forms and to $\mathrm{CeO}_{2}-\mathrm{NP}$ exposure. We chose to study $\mathrm{N}$ because $\mathrm{CeO}_{2}$-NPs modified $\mathrm{N}$ and ${ }^{15} \mathrm{~N}$ abundance in wheat (Rico et al., 2017), and we chose wheat and barley because these species vary in response to $\mathrm{CeO}_{2}-\mathrm{NPs}$ exposure, possibly indicating different modes of action (Rico et al., 2014, 2015a). We tested $500 \mathrm{mg} \mathrm{CeO}_{2}$ $\mathrm{NPs} / \mathrm{L}$ because this exposure level in soil altered roots, shoots, and grains $\delta^{15} \mathrm{~N}$ in wheat (Rico et al., 2017).

\section{Materials and methods}

\subsection{Experimental design}

This study was performed using the same $\mathrm{CeO}_{2}$-NPs (Meliorum Technologies, Rochester, NY) previously used in wheat (Rico et al., 2014, 2015a, 2017). The $\mathrm{CeO}_{2}-\mathrm{NPs}$ have been characterized as rods with primary size of $67 \pm 8 \times 8 \pm 1 \mathrm{~nm}$, particle size of $231 \pm 16 \mathrm{~nm}$ in DI water, surface area of $93.8 \mathrm{~m}^{2} / \mathrm{g}$, and $95.14 \%$ purity (Keller et al., 2010). A 10-day hydroponic experiment was performed using 0 and $500 \mathrm{mg} \mathrm{CeO}_{2}-\mathrm{NPs} / \mathrm{L}$ (Ce- 0 and $\mathrm{Ce}-500$, respectively) at three different $\mathrm{N}$ sources: ammonium nitrate $\left(\mathrm{NH}_{4} \mathrm{NO}_{3}\right)$, ammonium alone $\left(\mathrm{NH}_{4}{ }^{+}\right)$, and nitrate alone $\left(\mathrm{NO}_{3}{ }^{-}\right)$. Unmodified Yoshida nutrient solution (Yoshida et al., 1976) was used for the ammonium nitrate experiment. For ammonium or nitrate alone experiments, the amount of $\mathrm{N}$ in ammonium nitrate was replaced with equal molar 
concentrations of $\mathrm{NH}_{4} \mathrm{Cl} /\left(\mathrm{NH}_{4}\right)_{2} \mathrm{SO}_{4}$ or $\mathrm{KNO}_{3} / \mathrm{Ca}\left(\mathrm{NO}_{3}\right)_{2}$. The experiment had six treatment combinations with six replicates for each treatment.

\subsection{Plant cultivation and management}

The nanomaterial suspensions were prepared as previously described in Rico et al. (2017). The nutrient solution $(100 \mathrm{~mL}$ ) was placed in $150-\mathrm{mL}$ plastic jars (Nalgene, Rochester, NY). $\mathrm{CeO}_{2}$-NPs were added to the solution then sonicated for 30 mins at $20^{\circ} \mathrm{C}$ with occasional stirring. After sonication, the jars were covered with caps that had three holes where cuttings from $3 \mathrm{~mL}$ plastic pipette were fitted to hold two plants and air pumps (Aqua Supreme Air Pump, Petco). Air was constantly supplied using air pumps. All materials used for the hydroponic experiment were sterile and soaked in $10 \%$ hypochlorite solution before use. Two nine-day-old wheat or seven-day-old barley seedlings were grown in nutrient solution in growth chamber (Environmental Growth Chamber, Chagrin Falls, OH) set at 16-h photoperiod, $20 / 10^{\circ} \mathrm{C}, 70 \%$ humidity, $300 \mu \mathrm{mol} / \mathrm{m}^{2}$-s. At harvest, root and shoot were separated, washed thoroughly with Milli-Q water. After drying in the oven, total biomass was measured. Plant materials were ground and subjected to $\mathrm{N}$ and ${ }^{15} \mathrm{~N}$ analysis.

\subsection{Analysis of $\delta^{15} \mathrm{~N}$}

The analysis of $\mathrm{N}$ and $\delta^{15} \mathrm{~N}$ was performed using an Elementar Vario Isotope Cube (Elementar Analysensysteme GmbH, Hanau, Germany) interfaced to a Isoprime 100 isotope ratio mass spectrometer (Isoprime Ltd, Stockport UK) as described in Rico et al. (2017) Three laboratory isotope standards were analyzed to assess quality assurance or check calibration. The final values were expressed relative to Air as internal standard. The $\delta^{15} \mathrm{~N}$ values (\%o) of the $\mathrm{N}$ source were: $\mathrm{NH}_{4} \mathrm{NO}_{3}(4.98 \pm 0.18), \mathrm{NH}_{4}{ }^{+}(-1.76 \pm 0.61)$, and $\mathrm{NO}_{3}{ }^{-}$ (3.21 \pm 0.25$)$. Whole-plant $\delta^{15} \mathrm{~N}$ was calculated according to Robinson et al. (2000) as shown below. Whole-plant $\delta^{15} \mathrm{~N}$ discrimination occurs when whole-plant $\delta^{15} \mathrm{~N}$ is statistically lower than $\delta^{15} \mathrm{~N}$ of the $\mathrm{N}$ source $\left(\delta^{15} \mathrm{~N}_{\mathrm{s}}\right)$. Similarly, root or shoot $\delta^{15} \mathrm{~N}$ discrimination occurs when root or shoot $\delta^{15} \mathrm{~N}$ is statistically lower than $\delta^{15} \mathrm{~N}_{\mathrm{s}}$.

$$
\begin{aligned}
& \text { Whole plant } \delta^{15}(\%)= \\
& \frac{\left(\text { Shoot } \delta^{15} N \times \text { Shoot } N\right)+\left(\text { Root } \delta^{15} N \times \text { Root } N\right)+\left(\text { Grain } \delta^{15} N \times \text { Grain } N\right)}{\text { Shoot } N+\text { Root } N+\operatorname{Grain} N}
\end{aligned}
$$

\subsection{Synchrotron micro-XRF and micro-XANES analysis}

Wheat and barley shoots were harvested at the end of the experiment. The shoots were washed thoroughly with Milli-Q water, flash-frozen in liquid nitrogen, and kept at $-80^{\circ} \mathrm{C}$. The frozen young leaves ( $\sim 2.5 \mathrm{~cm}$ from the tip) were mounted, using a tiny amount of silicone grease, onto a Peltier stage and kept at $-27^{\circ} \mathrm{C}$ to reduce radiation damage (Freeman et al., 2006). The $\mu$-X-ray fluorescence ( $\mu \mathrm{XRF}$ ) and $\mu$-X-ray absorption near edge structure ( $\mu$ XANES) analysis of $\mathrm{Ce}$ at the $\mathrm{L}_{\mathrm{III}}$ edge in the frozen leaves was performed at 10.3.2 X-ray microprobe beamline at the Advanced Light Source (ALS) at Lawrence Berkeley National Laboratory following the method in Rico et al. $(2017,2018)$. The maps were collected with a $12(\mathrm{H}) \times 6(\mathrm{~V}) \mu \mathrm{m}^{2}$ beam at $15 \times 15 \mu \mathrm{m}^{2}$ pixel size and $50 \mathrm{~ms}$ dwell time at $5873 \mathrm{eV}$. Energy 
calibration was such that the first peak for $\mathrm{CeO}_{2}$ was at $5730.39 \mathrm{eV}$. Cerium $\mathrm{L}_{\mathrm{III}}$-edge $\mu \mathrm{XANES}$ spectra were collected at points of interest based on the apparent presence of $\mathrm{Ce}$ at these locations as determined by the $\mu$ XRF chemistry maps collected on shoots. Pre- and post-edge normalization and least squares combination fitting (LCF) were performed with ALS BL10.3.2 software. The fractions of $\mathrm{Ce}$ in $\mathrm{Ce}$ (III) and $\mathrm{Ce}$ (IV) forms at each spot was determined from the fitting results. Reference standard $\mu$ XANES spectra for LCF analysis were those reported in Rico et al. (2018). Additional description of the methods was presented in Appendix B.

\subsection{Data analysis}

Statistical analyses were performed using SAS statistical package (SAS Institute, Cary, NC, USA). Two-way ANOVA was performed separately for wheat and barley. $\mathrm{CeO}_{2}-\mathrm{NPs}$ (CE) was the main factor with Ce- 0 and $\mathrm{Ce}-500$ as the treatments while $\mathrm{N}$ source (NS) was another factor composed of $\mathrm{NH}_{4} \mathrm{NO}_{3}, \mathrm{NH}_{4}{ }^{+}$, and $\mathrm{NO}_{3}{ }^{-}$treatments. Whole-plant or organlevel (root or shoot) $\delta^{15} \mathrm{~N}$ discriminations were calculated. Statistical differences between $\delta^{15} \mathrm{~N}$, biomass, $\mathrm{N}$ concentration, $\mathrm{N}$ contents at $\mathrm{Ce}-0$ and $\mathrm{Ce}-500$ plants were also analyzed. Global mean $\mathrm{N}$ and $\delta^{15} \mathrm{~N}$ were calculated to measure effects of $\mathrm{CeO}_{2}-\mathrm{NPs}$ across different $\mathrm{N}$ sources.

\section{Results}

\subsection{Treatment effects and global mean calculations}

The table of two-way ANOVA with $\mathrm{CE}\left(\mathrm{CeO}_{2}\right.$-NPs treatments) and $\mathrm{NS}$ ( $\mathrm{N}$ source) as main factors is presented in Appendix C (Tables C.1 and C.2). For wheat, NS was significant for all parameters measured while $\mathrm{CE}$ was significant only for every biomass, $\mathrm{N}$ contents, and $\delta^{15} \mathrm{~N}$ measurements (Table C.1). In barley, NS was also significant for all parameters except root $\mathrm{N}$ concentration, whereas $\mathrm{CE}$ was significant only for total shoot and plant $\mathrm{N}$ contents, root $\mathrm{N}$ concentration, and root $\delta^{15} \mathrm{~N}$ (Table C.2). The global mean of CE (mean across different $\mathrm{N}$ sources) were calculated and presented in Table 1. Ce-500 did not affect $\mathrm{N}$ concentration but decreased biomass, and all $\mathrm{N}$ contents and $\delta^{15} \mathrm{~N}$ in wheat, but increased global mean shoot and plant $\mathrm{N}$, root $\mathrm{N}$ concentration, and root $\delta^{15} \mathrm{~N}$ in barley.

\subsection{Changes in biomass, $\mathrm{N}$ concentration, and total $\mathrm{N}$ content between $\mathrm{Ce}-\mathrm{O}$ and $\mathrm{Ce}-500$ plants are dependent on $\mathrm{N}$ source}

In wheat, $\mathrm{CeO}_{2}$-NPs only affected biomass production when $\mathrm{NH}_{4} \mathrm{NO}_{3}$ was used as the $\mathrm{N}$ source (Table 2). Ce-500 decreased both root and shoot dry weights (22 and $95 \mathrm{mg}$, respectively) compared to Ce-0 (40 and $123 \mathrm{mg}$, respectively). These decreases resulted in consistently lower root, shoot, and total $\mathrm{N}$ contents in Ce-500 (563, 2155, and $4393 \mu \mathrm{g}$, respectively) compared to the control (1001, 3055, and $4607 \mu \mathrm{g}$, respectively) (Figures 1A, $\mathrm{C}$ and E). Differences in $\mathrm{N}$ concentrations between Ce- 0 and Ce-500 were not statistically significant (Table 1), but Ce-500 increased shoot and total $\mathrm{N}$ contents compared to $\mathrm{Ce}-0$ in $\mathrm{NH}_{4}{ }^{+}$. Ce-500 also had higher shoot $\mathrm{N}$ content in $\mathrm{NO}_{3}{ }^{-}$compared to Ce-0 (Figure 1C).

For barley, significant differences between $\mathrm{Ce}-0$ and Ce-500 treated plants were only observed in $\mathrm{NH}_{4}{ }^{+}$(Table 1): root biomass increased at Ce-500 (10 mg) compared to Ce-0 (7 
$\mathrm{mg}$ ) while root $\mathrm{N}$ concentration (2.93\%) decreased and shoot $\mathrm{N}$ concentration $(2.75 \%)$

increased at Ce-500 relative to control (3.38\% and $2.31 \%$, respectively). However, $\mathrm{N}$ contents were much higher in the Ce-500 treatment than in Ce- 0 controls in $\mathrm{NH}_{4}{ }^{+}$(Figures $1 \mathrm{~B}, \mathrm{D}$ and F). Ce-500 also increased root and shoot $\mathrm{N}$ contents in the $\mathrm{NH}_{4} \mathrm{NO}_{3}$ treatment (Figures 1B and D).

\subsection{Ce-500 modifications in whole-plant and organ $\delta^{15} \mathrm{~N}$ are $\mathrm{N}$ source dependent}

For wheat, Ce- 0 and Ce-500 induced whole-plant $\delta^{15} \mathrm{~N}$ discrimination (i.e. $\delta^{15} \mathrm{~N}$ of wholeplant was lower than the source) in $\mathrm{NH}_{4} \mathrm{NO}_{3}$ (Figure 2A). However, only Ce-500 in $\mathrm{NH}_{4}{ }^{+}$ resulted in whole-plant $\delta^{15} \mathrm{~N}$ discrimination $(-1.48 \%$ ) with a simultaneous decrease in whole-plant $\delta^{15} \mathrm{~N}(-3.24 \%$ ) compared to the Ce-0 control (-2.74\%o) (Figure 2C). In barley, the only shift observed was that Ce-500 had higher whole-plant $\delta^{15} \mathrm{~N}(4.96 \%$ o $)$ than Ce-0 (3.88\%o) when $\mathrm{NH}_{4} \mathrm{NO}_{3}$ was the $\mathrm{N}$ source (Figure 2B).

Figure 3 displays the effects of $\mathrm{CeO}_{2}$-NPs on $\delta^{15} \mathrm{~N}$ discriminations (i.e. $\delta^{15} \mathrm{~N}$ of shoot was lower than the source) at the organ level. In wheat, Ce-500 induced root $\delta^{15} \mathrm{~N}$ discriminations in $\mathrm{NH}_{4} \mathrm{NO}_{3}$ and $\mathrm{NH}_{4}{ }^{+}(-1.74 \%$ ond $-1.69 \%$, respectively) (Figures $3 \mathrm{~A}$ and C). In barley, discrimination against ${ }^{15} \mathrm{~N}$ was not observed. Instead, Ce-500 increased root $\delta^{15} \mathrm{~N}_{\text {in }} \mathrm{NH}_{4} \mathrm{NO}_{3}$ and $\mathrm{NO}_{3}{ }^{-}(0.86 \%$ and $1.29 \%$, respectively) compared to Ce-0 (Figures 3B and $\mathrm{F}$ ).

Results also revealed significant differences in root and shoot $\delta^{15} \mathrm{~N}$ between Ce- 0 and Ce-500 treated plants. For wheat in $\mathrm{NH}_{4} \mathrm{NO}_{3}$ and $\mathrm{NH}_{4}{ }^{+}$, Ce-500 decreased root $\delta^{15} \mathrm{~N}(3.23$ and $-2.25 \%$, respectively) compared to Ce-0 (4.96 and $-1.27 \%$, respectively), but in $\mathrm{NO}_{3}{ }^{-}$ Ce-500 increased root $\delta^{15} \mathrm{~N}(3.27 \%$ ) compared to the Ce- 0 treatment $(2.60 \%$ ) and to a level that root and shoot $\delta^{15} \mathrm{~N}$ (3.27\% and 3.16\%o, respectively) were statistically (Figures 3A, C, and $\mathrm{E}$ ). In barley, statistical differences were observed in $\mathrm{NO}_{3}{ }^{-}$only: Ce-500 increased shoot $\delta^{15} \mathrm{~N}(4.62 \%$ ) compared to Ce-0 (3.61\%o) (Figure 3B).

\subsection{In-situ imaging of $\mathrm{CeO}_{2}$-NPs in plant shoots}

The synchrotron micro-XRF images revealed the presence of $\mathrm{CeO}_{2}-\mathrm{NPs}$ in the shoots of wheat and barley at different $\mathrm{N}$ sources (Figure 4). The micro-XANES analysis showed that Ce was present in greater amount as $\mathrm{CeO}_{2}(80-93 \%)$ and $\mathrm{Ce}(\mathrm{IV})$ to $\mathrm{Ce}(\mathrm{III})$ reduction (719\%) occurred to a much lesser extent (Figure 4, Table D.1).

\section{Discussion}

Our results led to rejection of all three hypotheses tested in this study. $\mathrm{N}$ uptake and metabolism plays a central role in all cellular functions in plants, and the shifts observed here in response to $\mathrm{CeO}_{2}-\mathrm{NP}$ exposure indicate that ENMs have the potential to alter how important nutrients such as $\mathrm{N}$ are utilized in plants, even when toxicity is not evident. Our hydroponic experiments removed the chemical and biological complexity of interactions that occur at the root-soil interface in soils in order to better understand possible mechanisms underlying changes in $\mathrm{N}$ uptake and metabolism in the two species. Additional studies will be needed to examine $\mathrm{CeO}_{2}-\mathrm{NP}$ and $\mathrm{N}$ interactions in soil-grown plants, and to evaluate the longer-term consequences of changes in $\mathrm{N}$ dynamics in plants exposed to $\mathrm{CeO}_{2}-\mathrm{NPs}$. 


\subsection{Effects of $\mathrm{CeO}_{2}-\mathrm{NPs}$ on $\mathrm{N}$ metabolism in wheat}

$\mathrm{CeO}_{2}$-NPs did not affect the root influx of $(\mathrm{N})_{\text {inorg }}$ from $\mathrm{NH}_{4}{ }^{+}$since total plant and shoot $\mathrm{N}$ contents increased without changes in biomass and $\mathrm{N}$ concentration (Table 2, Figure $1 \mathrm{C}$ and E). However, the very high whole-plant and shoot $\delta^{15} \mathrm{~N}$ discriminations (i.e. $\delta^{15} \mathrm{~N}$ of wholeplant and shoot was lower than the source) in Ce-500 coupled with its low root $\delta^{15} \mathrm{~N}$ compared to Ce-0 strongly suggest low influx of ${ }^{15} \mathrm{~N}$ into the roots or high efflux of ${ }^{15} \mathrm{~N}$ enriched $(\mathrm{N})_{\text {inorg }}$ to outside roots (Figure A.1). A previous study showed that discrimination in $\mathrm{NH}_{4}{ }^{+}$uptake could result from efflux of ${ }^{15} \mathrm{~N}$-enriched $\mathrm{NH}_{4}{ }^{+}$from $(\mathrm{N})$ inorg (Figure A.1) (Evans et al., 1996). This could happen when $\mathrm{NH}_{4}{ }^{+}$gets assimilated immediately in the roots which increases the pool of ${ }^{15} \mathrm{~N}$-enriched $\mathrm{NH}_{4}{ }^{+}$, then the ${ }^{15} \mathrm{~N}$-enriched $\mathrm{NH}_{4}{ }^{+}$are transported out of the roots. Due to its toxicity, $\mathrm{NH}_{4}{ }^{+}$, generally is rapidly assimilated or flushed out of the roots (Evans et al., 1996).

In contrast, data seem to suggest that $\mathrm{CeO}_{2}-\mathrm{NPs}$ decreased root to shoot translocation of ${ }^{15} \mathrm{~N}$ (either $\mathrm{T}_{\mathrm{o}}$ or $\mathrm{T}_{\mathrm{i}}$ in Figure A.1) when the wheat seedlings were grown in $\mathrm{NO}_{3}{ }^{-}$because root $\delta^{15} \mathrm{~N}$ increased to similar level with shoot $\delta^{15} \mathrm{~N}$ despite decreased shoot $\mathrm{N}$ content and a lack of net change in whole-plant $\delta^{15} \mathrm{~N}$ discrimination (Figure 1C, 2E, 3E).

Wheat was a good discriminator of ${ }^{15} \mathrm{~N}$ when the $\mathrm{N}$ source was $\mathrm{NH}_{4} \mathrm{NO}_{3}$ as shown by notable whole-plant and shoot $\delta^{15} \mathrm{~N}$ discriminations in Ce-0. Exposure to $\mathrm{CeO}_{2}-\mathrm{NPs}$ only increased root $\delta^{15} \mathrm{~N}$ discrimination despite remarkable decreases in biomass production and $\mathrm{N}$ content. The decrease in root $\delta^{15} \mathrm{~N}$ was probably due to the discrimination against ${ }^{15} \mathrm{~N}$ similar to what was observed in wheat in $\mathrm{NH}_{4}{ }^{+}$. It is also probable that shoot $\delta^{15} \mathrm{~N}$ from Ce- 0 and Ce-500 was from $\delta^{15} \mathrm{~N}$ of the source $\mathrm{NO}_{3}{ }^{-}$, and the decrease root $\delta^{15} \mathrm{~N}$ was due to discrimination against ${ }^{15} \mathrm{~N}$ from $\mathrm{NH}_{4}{ }^{+}$. Previous reports also showed that lower $\mathrm{N}$ uptake decreased ${ }^{15} \mathrm{~N}$ abundance in Cd-treated aquatic moss (Sutter et al., 2002). In another report, alfalfa plants that exhibited impaired growth features when subjected to high carbon dioxide concentration and water deficiency had negative leaf $\delta^{15} \mathrm{~N}$ values (Ariz et al., 2015). In this study, $\mathrm{N}$ concentration in both shoot and root did not differ between Ce-500 and Ce-0 indicating that $\mathrm{CeO}_{2}$-NPs did not affect $\mathrm{N}$ uptake and that reduced total $\mathrm{N}$ content was due to low plant biomass. It is possible that low biomass was due to reduction in macromolecules such as fatty acids and lignins similar to what was observed in rice seedlings exposed to $\mathrm{CeO}_{2}$-NPs (Rico et al., 2013).

\subsection{Effects of $\mathrm{CeO}_{2}-\mathrm{NPs}$ on $\mathrm{N}$ metabolism in barley}

In contrast to what was observed in wheat, $\mathrm{CeO}_{2}-\mathrm{NPs}$ did not interfere with ${ }^{15} \mathrm{~N}$ incorporation in barley and even increased whole-plant and organ $\delta^{15} \mathrm{~N}$, signifying that root $(\mathrm{N})_{\text {inorg }}$ in Ce-500 plants was converted to $(\mathrm{N})_{\text {org }}$ and efflux of ${ }^{15} \mathrm{~N}$-enriched $(\mathrm{N})_{\text {inorg }}$ did not occur. We believe this is consistent with the mechanism in Figure A.1 since the data showed that Ce-500 increased $\delta^{15} \mathrm{~N}$ values, especially in $\mathrm{NH}_{4} \mathrm{NO}_{3}$ and $\mathrm{NO}_{3}{ }^{-}$, without the increase in $\mathrm{N}$ content. Previous studies have also reported ${ }^{15} \mathrm{~N}$ enrichment in needles of Norway spruce (Picea abies) and wheat due to environmental stress (i.e. declining forest and ozone exposure) (Gebauer and Schulze, 1991; Hofmann et al., 1997). It is not clear why wheat and barley exhibited very different responses on $\mathrm{N}$ uptake when exposed to $\mathrm{CeO}_{2}-\mathrm{NPs}$. Whether 
these differences were due to root structure, nanoparticle dissolution in the root, or physiological changes in plant need to be elucidated in future studies.

\section{3 $\mathrm{CeO}_{2}-\mathrm{NPs}$ translocation in wheat and barley shoots}

The synchrotron micro-XRF analysis showed that both wheat and barley translocated $\mathrm{CeO}_{2}$ NPs to the shoots regardless of N source in the growth media (Figure 4). We have shown in previous hydroponic studies the uptake of $\mathrm{Ce}$ in wheat and barley seedlings (Rico et al., 2015 b), which corroborates the plant uptake of $\mathrm{CeO}_{2}-\mathrm{NPs}$ recorded in the current study. Our data on speciation is in agreement with data normally reported in the literature regarding the accumulation of $\mathrm{CeO}_{2}$-NPs in plants grown in hydroponic culture solution (Rico et al., 2013; Spielman-Sun et al., 2017; Zhang et al., 2012). Unfortunately, the data does not allow further speciation analysis to determine which part of the plants the reduction occurred. Our findings also revealed that $\mathrm{CeO}_{2}-\mathrm{NPs}$ were translocated to the shoots suggesting an uptake of $\mathrm{CeO}_{2}$-NPs in barley plants; however, barley seedlings did not exhibit decreases in biomass or ${ }^{15} \mathrm{~N}$ uptake (Table 2, Figures 2 and 3). More studies should be performed to understand why $\mathrm{CeO}_{2}$-NPs markedly disturbed $\mathrm{N}$ or ${ }^{15} \mathrm{~N}$ uptake in wheat than barley.

\section{Conclusion}

The goal of this study was to determine if $\mathrm{CeO}_{2}-\mathrm{NP}$ exposure altered the uptake or apparent metabolism of $\mathrm{N}$ by two commercially important plant species. We used hydroponic culture in order to control the amount, the forms and isotopic composition of $\mathrm{N}$ supplied to the plants during exposure. We found that decreases in $\delta^{15} \mathrm{~N}$ in wheat were due to low assimilation of $(\mathrm{N})_{\text {inorg }}$ and efflux of ${ }^{15} \mathrm{~N}$-enriched $(\mathrm{N})_{\text {inorg }}$ while increases in $\delta^{15} \mathrm{~N}$ in barley were probably due to conversion of all $(\mathrm{N})_{\text {inorg }}$ to $(\mathrm{N})_{\text {org }}$. The study also revealed that rootto-shoot translocation of $\mathrm{CeO}_{2}-\mathrm{NPs}$ without negative effects on $\mathrm{N}$ and ${ }^{15} \mathrm{~N}$ dynamics in barley. Although the longer-term consequences of shifts in isotopic $\mathrm{N}$ are unknown, they clearly show the potential for ENMs to interfere with plant metabolism of critical plant nutrients. Additional studies will be needed to determine the extent to which these metabolic changes occur in soils containing intact root-rhizospheres, and also whether these changes lead to shifts in nutrient dynamics in terrestrial ecosystems.

\section{Acknowledgments}

The authors would like to thank R. Brooks and W. Rugh for assistance in conducting the stable isotope measurements and for thoughtful discussions regarding the data. We thank S. Perakis for his comments on an earlier version of this manuscript. The information in this document was funded by the U.S. Environmental Protection Agency. It has been subjected to the agency's peer and administrative review, and it has been approved for publication as a U.S. Environmental Protection Agency document. Mention of trade names or commercial products does not constitute endorsement or recommendation for use. The operations at the Advanced Light Source are supported by the Director, Office of Science, Office of Basic Energy Sciences, US Department of Energy under Contract No. DE-AC02-05CH11231. 


\section{Appendix}

\section{Appendix A.: Nitrogen transport processes in plant}

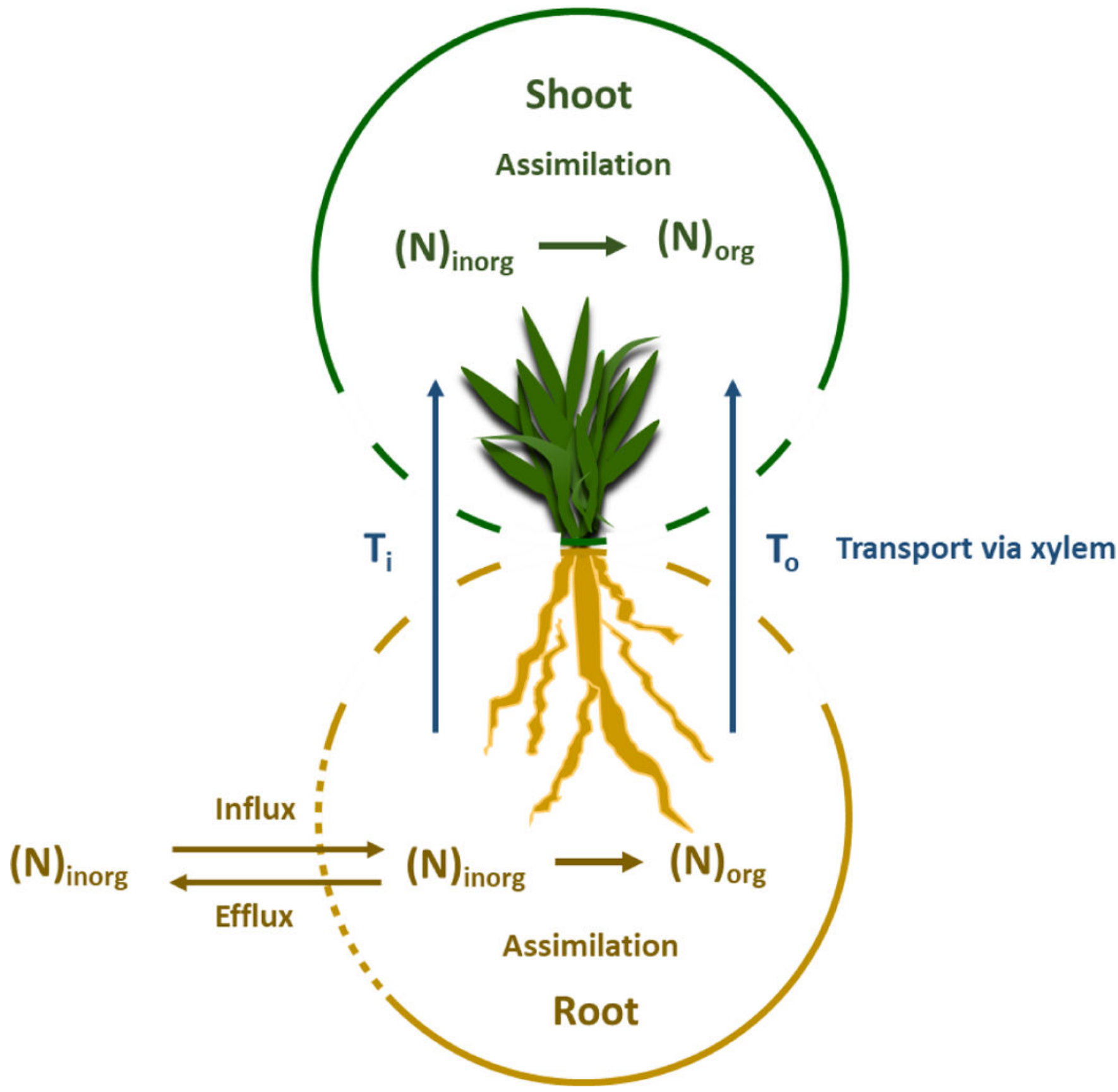

Figure A.1.

Transport processes causing isotopic $\delta^{15} \mathrm{~N}$ discrimination observed in plants as described in the literature (Kalcsits et al. (2014), copyright license granted by John Wiley and Sons). $(\mathrm{N})_{\text {org }}=$ organic $\mathrm{N},(\mathrm{N})_{\text {inorg }}=$ inorganic $\mathrm{N}, \mathrm{T}_{\mathrm{o}}=(\mathrm{N})_{\text {org }}$ transport, $\mathrm{T}_{\mathrm{i}}=(\mathrm{N})_{\text {inorg }}$ transport. 


\section{Appendix B.: Synchrotron analysis}

Small amounts of these mixtures were sprinkled onto the adhesive side of Kapton tape and covered with another piece of Kapton tape and presented to the $\mu$ XRF beamline at room temperature. The beam energy was calibrated so that the first peak for $\mathrm{CeO}_{2}-\mathrm{NPs}$ was at $5730.39 \mathrm{eV}$. Data were taken with a fine spacing near $5848.6 \mathrm{eV}$, where a monochromator Bragg glitch served as an internal energy calibrant for each spectrum. The short dwell time in this region is the source of the noisiness of all spectra there. Because the white-line intensity is high, the fluorescence spectra for the $\mathrm{Ce}(\mathrm{III})$ references are very sensitive to overabsorption ("self-absorption") (Goulon et al., 1981; Manceaue et al., 2002). Therefore, we took spectra at places where the intensity was high, for good signal, and at tiny particles, where the spectra were noisy but the same for a range of particles which yielded different count rates. We thus considered that these particles were small enough to avoid overabsorption, and adjusted the spectra from the stronger-signal areas using a simple model for overabsorption with the amount of overabsorption varied so the spectral shapes for the strong-signal areas matched those for the tiny particles. This procedure gives us the signal quality from the strong-signal areas and the freedom from overabsorption found with small particles.

Reference standard XANES spectra for LCF were obtained from Ce(IV) oxide nanoparticles, $\mathrm{Ce}$ (III) acetate, $\mathrm{Ce}$ (III) carbonate, $\mathrm{Ce}(\mathrm{III})$ oxalate, and $\mathrm{Ce}(\mathrm{III})$ phosphate. The standards were prepared by blending a 1:1 (w/w) ratio of the standards and boron carbide $\left(\mathrm{B}_{4} \mathrm{C}\right)$ with a clean agate mortar and pestle. Linear combination fit $(\mathrm{LCF})$ analysis was performed with $\mathrm{Ce}(\mathrm{III})$ species standards was performed on their $\mu$ XANES spectra; however, LCF values obtained were not significantly different from each other that fit from one $\mathrm{Ce}(\mathrm{III})$ species was used (Appendix D.1).

\section{Appendix C.: ANOVA of wheat or barley exposed to cerium oxide nanoparticles}

Table C.1.

Two-way ANOVA of biomass, $\mathrm{N}$ and $\delta^{15} \mathrm{~N}$ in wheat exposed to cerium oxide nanoparticles. ${ }^{a}$

\begin{tabular}{|c|c|c|c|}
\hline Treatment & CE & NS & $\mathrm{CE} \times \mathrm{NS}$ \\
\hline Root biomass & $0.0067 * * *$ & $<0.0001 * * * *$ & $0.0079 * * *$ \\
\hline Shoot biomass & $0.0840^{* *}$ & $<0.0001 * * * * *$ & $0.0343 * *$ \\
\hline Root \% N & $0.5421^{\mathrm{ns}}$ & $<0.0001 * * * *$ & $0.3352^{\mathrm{ns}}$ \\
\hline Shoot $\% \mathrm{~N}$ & $0.4046^{\mathrm{ns}}$ & $0.0003 * * * *$ & $0.0956^{*}$ \\
\hline Total $\operatorname{root} \mathrm{N}$ & $0.5421^{\mathrm{ns}}$ & $<0.0001 * * * *$ & $0.3352^{\mathrm{ns}}$ \\
\hline Total shoot $\mathrm{N}$ & $0.0723^{*}$ & $0.0009 * * * *$ & $0.0090 * * *$ \\
\hline Total plant $\mathrm{N}$ & $0.0127^{* *} *$ & $<0.0001 * * * *$ & $0.0004 * * *$ \\
\hline Root $\delta^{15} \mathrm{~N}$ & $0.0047 * * *$ & $<0.0001 * * * *$ & $0.0004 * * *$ \\
\hline Shoot $\delta^{15} N$ & $0.0920^{*}$ & $<0.0001 * * * *$ & $0.6279^{\mathrm{ns}}$ \\
\hline Whole-plant $\delta^{15} \mathrm{~N}$ & $0.0369 * *$ & $<0.0001 * * * *$ & $0.0027 * * *$ \\
\hline
\end{tabular}


${ }^{a} \mathrm{CE}=\mathrm{CeO}_{2}-\mathrm{NPs}$ as the main factor with $\mathrm{Ce}-0$ and $\mathrm{Ce}-500$ as the treatments, $\mathrm{NS}=\mathrm{N}$ source as another factor composed of $\mathrm{NH}_{4} \mathrm{NO}_{3}, \mathrm{NH}_{4}{ }^{+}$, and $\mathrm{NO}_{3}{ }^{-}$treatments. Statistical significance at $\mathrm{P} \leq 0.10,0.05$, and 0.001 was indicated as *, **, and ***, respectively. ns indicates no significance.

Table C.2.

Two-way ANOVA of biomass, $\mathrm{N}$ and $\delta^{15} \mathrm{~N}$ in barley exposed to cerium oxide nanoparticles. ${ }^{a}$

\begin{tabular}{|c|c|c|c|}
\hline Treatment & $\mathbf{C E}$ & NS & $\mathrm{CE} \times \mathrm{NS}$ \\
\hline Root biomass & $0.1069^{\mathrm{ns}}$ & $<0.0001 * * * *$ & $0.9286^{\mathrm{ns}}$ \\
\hline Shoot biomass & $0.2457^{\mathrm{ns}}$ & $0.0013^{* * *}$ & $0.8868^{\mathrm{ns}}$ \\
\hline Root $\% \mathrm{~N}$ & $0.0811^{*}$ & $0.1755^{\mathrm{ns}}$ & $0.9875^{\mathrm{ns}}$ \\
\hline Shoot $\% \mathrm{~N}$ & $0.4464^{\mathrm{ns}}$ & $0.0034^{* * * *}$ & $0.4193^{\mathrm{ns}}$ \\
\hline Total $\operatorname{root} \mathrm{N}$ & $0.1088^{\mathrm{ns}}$ & $<0.0001 * * * *$ & $0.4859^{\mathrm{ns}}$ \\
\hline Total shoot $\mathrm{N}$ & $0.0344 * *$ & $<0.0001 * * * *$ & $0.3566^{\mathrm{ns}}$ \\
\hline Total plant $\mathrm{N}$ & $0.0270 * *$ & $<0.0001 * * * *$ & $0.3316^{\mathrm{ns}}$ \\
\hline Root $\delta^{15} \mathrm{~N}$ & $0.0479 * *$ & $<0.0001 * * * *$ & $0.5821^{\mathrm{ns}}$ \\
\hline Shoot $\delta^{15} \mathrm{~N}$ & $0.2139^{\mathrm{ns}}$ & $<0.0001 * * * * *$ & $0.2435^{\mathrm{ns}}$ \\
\hline Whole-plant $\delta^{15} \mathrm{~N}$ & $0.1138^{\mathrm{ns}}$ & $<0.0001$ ***** & $0.2707^{\mathrm{ns}}$ \\
\hline
\end{tabular}

${ }^{a} \mathrm{CE}=\mathrm{CeO}_{2}-\mathrm{NPs}$ as the main factor with $\mathrm{Ce}-0$ and $\mathrm{Ce}-500$ as the treatments, $\mathrm{NS}=\mathrm{N}$ source as another factor composed of $\mathrm{NH}_{4} \mathrm{NO}_{3}, \mathrm{NH}_{4}{ }^{+}$, and $\mathrm{NO}_{3}{ }^{-}$treatments. Statistical significance at $\mathrm{P} \leq 0.10,0.05$, and 0.001 was indicated as *, **, and ***, respectively. ns indicates no significance.

\section{Appendix D.: Linear combination fits (LCF) analysis}

Table D.1.

Linear combination fits of Ce micro-XANES spectra obtained in shoots of wheat and barley exposed to cerium oxide nanoparticles $(500 \mathrm{mg} / \mathrm{L})$ for 10 days in hydroponic suspension supplied with different forms of N. NSS is the normalized sum-square error of the fit $\sum\left(y-y_{f i t}\right)^{2} / \sum y^{2}$ where $y$ and $y_{f i t}$ are the XANES spectrum and fit, respectively.

\begin{tabular}{cccc}
\hline N treatment & Plant & Ce LCF analysis & NSS \\
\hline $\mathrm{NH}_{4} \mathrm{NO}_{3}$ & Wheat & $80.91 \% \mathrm{CeO}_{2} \mathrm{NPs}+18.94 \% \mathrm{Ce}$ (III) & 0.000206 \\
& Barley & $92.41 \% \mathrm{CeO}_{2} \mathrm{NPs}+6.65 \% \mathrm{Ce}$ (III) & 0.000311 \\
$\mathrm{NH}_{4}{ }^{+}$ & Wheat & $88.28 \% \mathrm{CeO}_{2} \mathrm{NPs}+11.98 \% \mathrm{Ce}$ (III) & 0.000123 \\
& Barley & $88.12 \% \mathrm{CeO}_{2} \mathrm{NPs}+12.18 \% \mathrm{Ce}$ (III) & 0.000285 \\
$\mathrm{NO}_{3}{ }^{-}$ & Wheat & $92.65 \% \mathrm{CeO}_{2} \mathrm{NPs}+7.32 \% \mathrm{Ce}$ (III) & 0.001725 \\
& Barley & $91.89 \% \mathrm{CeO}_{2} \mathrm{NPs}+7.99 \% \mathrm{Ce}(\mathrm{III})$ & 0.000366 \\
\hline
\end{tabular}

\section{References}

Ariz I, Cruz C, Neves T, Irigoyen JJ, Garcia-Olaverri C, Nogues S, Aparicio-Tejo PM, Aranjuelo I, 2015 Leaf $\delta^{15} \mathrm{~N}$ as a physiological indicator of the responsiveness of $\mathrm{N}_{2}$-fixing alfalfa plants to elevated $\left[\mathrm{CO}_{2}\right]$, temperature and low water availability. Frontiers Plant Sci. 6, 574-584.

Banas D, Vollaire Y, Danger M, Thomas M, Oliveira-Ribeiro CA, Roche H, Ledore Y, 2009 Can we use stable isotopes for ecotoxicological studies? Effect of DDT on isotopic fractionation in Perca fluviatilis. Chemosphere 76, 734-739. [PubMed: 19576618]

Craine JM, Brookshire ENJ, Cramer MD, Hasselquis NJ, Koba K, Marin-Spiotta R, Wang L, 2015 Ecological interpretations of nitrogen isotope ratios of terrestrial plants and soils. Plant Soil 396, 126. 
Dahle JT, Arai Y, 2015 Environmental geochemistry of cerium: Applications and toxicology of cerium oxide nanoparticles. Int. J. Environ. Res. Public Health 12, 1253-1278. [PubMed: 25625406]

Evans RD, 2001 Physiological mechanisms influencing plant nitrogen isotope composition. Trends Plant Sci. 6, 121-126. [PubMed: 11239611]

Evans RD, Bloom AJ, Sukrapanna SS, Ehleginger JR, 1996 Nitrogen isotope composition to tomato (Lycopersicon Esculentum Mill. Cv. T-5) grown under ammonium or nitrate nutrition. Plant Cell Environ. 19, 1317-1323.

Freeman JL, Zhang LH, Marcus MA, Fakra S, McGrath SP, Pilon-Smits EAH, 2006 Spatial imaging, speciation, and quantification of selenium in the hyperaccumulator plants Astragalus bisulcatus and Stanleya pinnata. Plant Physiol. 142, 124-134. [PubMed: 16920881]

Gebauer G, Schulze ED, 1991 Carbon and nitrogen isotope ratios in different compartments of a healthy and declining Picea abies forest in the Fichtelgebirge, NE Bavaria. Oecologia 87, 198-207. [PubMed: 28313836]

Hofmann D, Jung K, Bender J, Gehre M, Schuurmann G, 1997 Using natural isotope variations of nitrogen in plants as an early indicator of air pollution stress. J. Mass Spectrom. 32, 855-863.

Kalcsits LA, Buschhaus HA, Guy RD, 2014 Nitrogen isotope discrimination as an integrated measure of nitrogen fluxes, assimilation and allocation in plants. Physiol. Plantarum. 151, 293-304.

Kalcsits LA, Guy RD, 2013 Whole-plant and organ-level nitrogen isotope discrimination indicates modification of partitioning of assimilation, fluxes and allocation of nitrogen in knockout lines of Arabidopsis Thaliana. Physiol. Plantarum 149, 249-259.

Keller AA, Wang H, Zhou D, Lenihan HS, Cherr G, Cardinale BJ, Miller R, Ji Z, 2010 Stability and aggregation of metal oxide nanoparticles in natural aqueous media. Environ. Sci. Technol. 44, 1962-1967. [PubMed: 20151631]

Manceau A, Marcus MA, Tamura N, 2002 "Quantitative speciation of heavy metals in soils and sediments by synchrotron X-ray techniques", in Applications of Synchrotron Radiation in LowTemperature Geochemistry and Environmental Science, Fenter P and Sturchio NC, Eds.Reviews in Mineralogy and Geochemistry, Mineralogical Society of America, Washington, DC., 49, 341-428.

Mariotti A, Mariotti F, Champigny ML, Amarger N, Moyse A, 1982 Nitrogen isotope fractionation associated with nitrate reductase activity and uptake of NO3- by pearl millet. Plant Physiol. 69, 880-884. [PubMed: 16662313]

Marshall JD, Brooks JR, and Lajtha K, 2007 Sources of variation in the stable isotopic composition of plants In Stable isotopes in Ecology and Environmental Science, Michener R and Lajtha K, Eds., Blackwell Publishing, Malden, MA, pgs. 22-60.

Rico CM, Barrios AC, Tan W, Rubenecia R, Lee SC, Varela-Ramirez A, Peralta-Videa JR, GardeaTorresdey JL, 2015a Physiological and biochemical response of soil-grown barley (Hordeum vulgare L.) to cerium oxide nanoparticles. Environ. Sci. Pollut. Res. 22, 10551-10558.

Rico CM, Johnson MG, Marcus MA, Andersen CP, 2017 Intergenerational responses of wheat (Triticum Aestivum L.) to cerium oxide nanoparticles exposure. Environ. Sci. Nano 4, 700-711. [PubMed: 30147938]

Rico CM, Johnson MG, Marcus MA, 2018 Cerium oxide nanoparticles transformation at the root-soil interface of barley (Hordeum vulgare L.). Environ. Sci. Nano DOI:10.1039/C8EN00316E

Rico CM, Lee SC, Rubenecia R, Mukherjee A, Hong J, Peralta-Videa JR, Gardea-Torresdey JL, 2014 Cerium oxide nanoparticles impact yield and modify nutritional parameters in wheat (Triticum aestivum L.). J. Agric. Food Chem. 62, 9669-9675. [PubMed: 25220448]

Rico CM, Morales MI, McCreary R, Castillo-Michel H, Barrios AC, Hong J, Tafoya A, Lee WY, Varela-Ramirez A, Peralta-Videa JR, Gardea-Torresdey JL, 2013 Cerium oxide nanoparticles modify the antioxidative stress enzyme activities and macromolecule composition in rice seedlings. Environ. Sci. Technol. 47, 14110-14008. [PubMed: 24266714]

Rico CM, Peralta-Videa JR, Gardea-Torresdey JL, 2015b Differential effects of cerium oxide nanoparticles on rice, wheat, and barley roots: A fourier transform infrared (FT-IR) microspectroscopy study. Appl. Spectrosc. 69, 287-295. [PubMed: 25587938]

Robinson D, Handley LL, Scrimgeour CM, Gordon DC, Forster BP, Ellis RP, 2000 Using stable isotope natural abundances $\left(\delta^{15} \mathrm{~N}\right.$ and $\left.\delta^{13} \mathrm{C}\right)$ to integrate the stress responses of wild barley (Hordeum Spontaneum C. Koch.) genotypes. J. Exp. Bot. 51, 41-50. [PubMed: 10938794] 
Schmidt AC, Reisser W, Mattusch J, Wennrich R, Jung K, 2004 Analysis of arsenic species accumulation by plants and the influence on their nitrogen uptake. J. Anal. At. Spectrom. 19, 172177.

Servin AD, White JC, 2016 Nanotechnology in agriculture: Next steps for understanding engineered nanoparticle exposure and risk. NanoImpact 1, 9-12.

Spielman-Sun E, Lombi E, Donner E, Howard D, Unrine JM, Lowry GV, 2017 Impact of surface charge on cerium oxide nanoparticle uptake and translocation by wheat (Triticum Aestivum). Environ. Sci. Technol. 51, 7361-7368. [PubMed: 28575574]

Sutter K, Jung K, Krauss GJ, 2002 Effects Of heavy metals on the nitrogen metabolism of the aquatic moss Fontnalis Antipyretica L. Ex Hedw. - A ${ }^{15} \mathrm{~N}$ tracer study. Environ. Sci. Pollut. Res 9, 417421.

Tamm CO, 1991, Nitrogen in Terrestrial Ecosystems: Questions of productivity, vegetational changes, and ecosystem stability Ecological Studies 81, Springer-Verlag Berlin Heidelberg, DOI: 10.1007/978-3-642-75168-4.

Unkovich M, 2013 Isotope discrimination provides new insight into biological nitrogen fixation. New Phytol. 198, 643-646. [PubMed: 23461709]

Yoshida S, Forno DA, Cock JH, Gomez KA, 1976 Laboratory Manual for Physiological Studies of Rice; International Rice Research Institute: Los Baños, Laguna, Philippines.

Zhang P, Ma Y, Zhang Z, He X, Zhang J, Guo Z, Tai R, Zhao Y, Chai Z, 2012 Biotransformation of ceria nanoparticles in cucumber plants. ACS Nano 6, 9943-9950. [PubMed: 23098040]

Zuverza-Mena N, Martinez-Fernandez D, Du W, Hernandez-Viezcas JA, Bonilla-Bird N, LopezMoreno ML, Komarek M, Peralta-Videa JR, Gardea-Torresdey JL, 2017 Exposure of engineered nanomaterials to plants: Insights into the physiological and biochemical responses - A review. Plant Physiol. Biochem. 110, 236-264. [PubMed: 27289187]

Goulon J; Goulon-Ginet C; Cortes R; Dubois JM On experimental attenuation factors of the amplitude of the EXAFS oscillations in absorption, reflectivity and luminescence measurements. J. Phys. 1981, 42, 539-548.

Manceau A; Marcus MA; Tamura N (2002) "Quantitative speciation of heavy metals in soils and sediments by synchrotron X-ray techniques", in Applications of Synchrotron Radiation in LowTemperature Geochemistry and Environmental Science, Fenter P and Sturchio NC, Eds.Reviews in Mineralogy and Geochemistry, Mineralogical Society of America, Washington, DC., 49, 341-428. 


\section{Wheat}
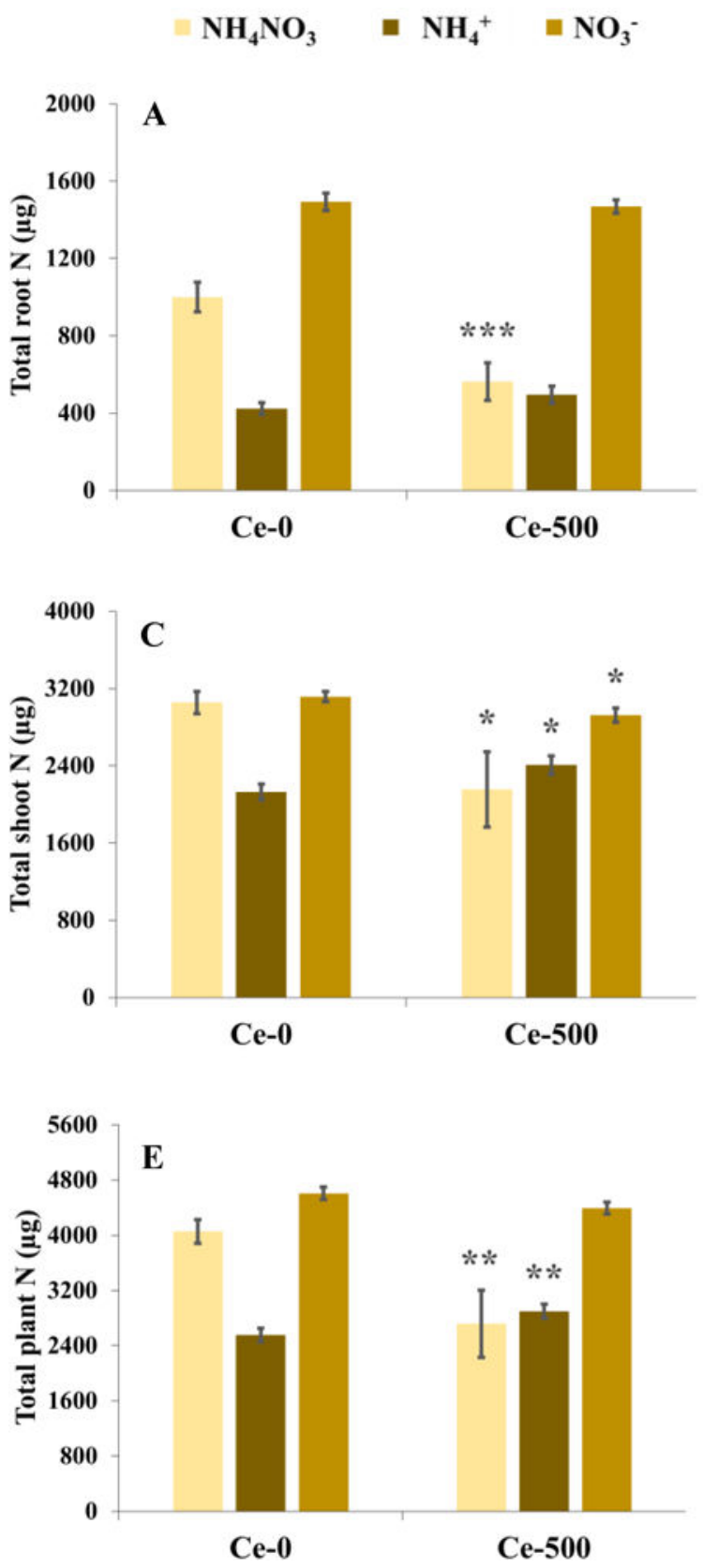

Barley
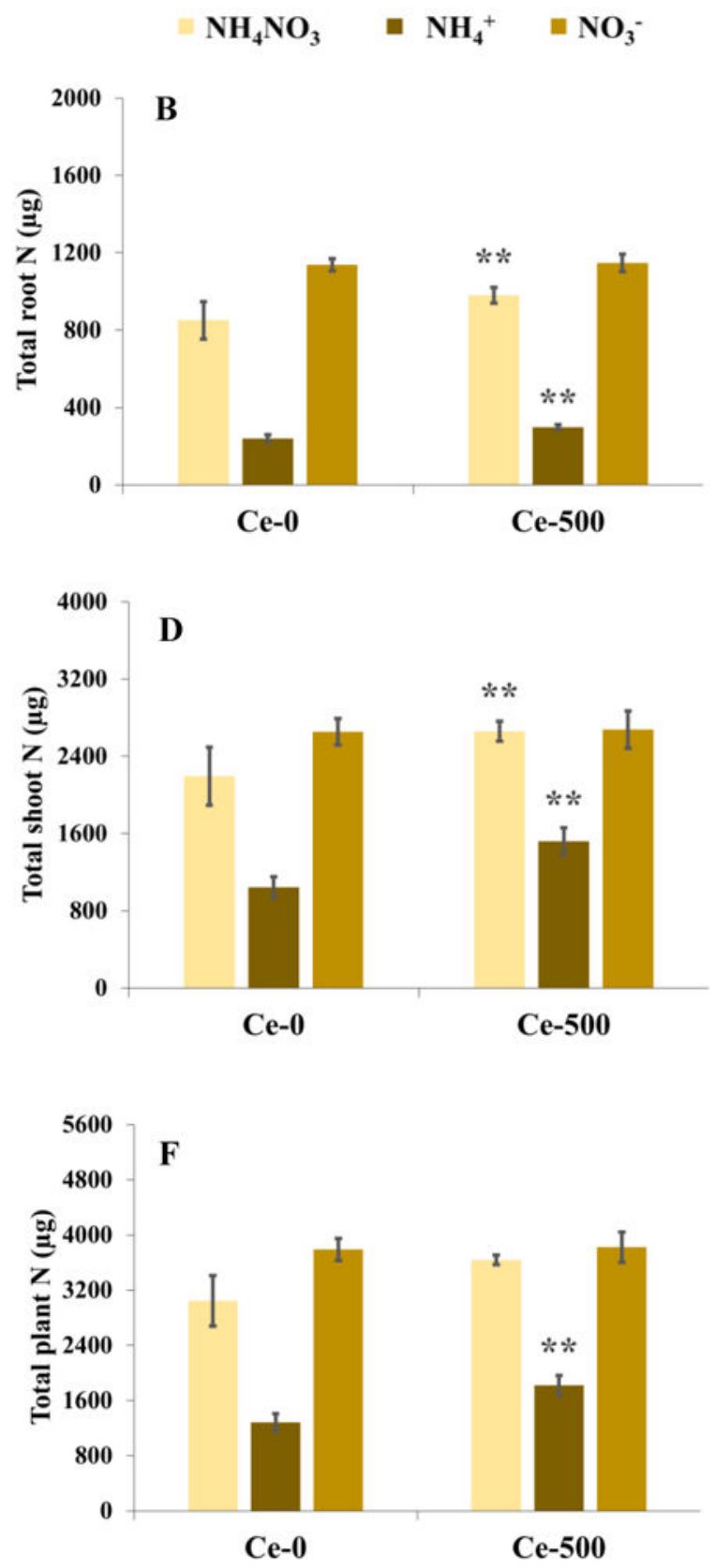

Figure 1.

$\mathrm{N}$ contents in wheat and barley exposed to $\mathrm{CeO}_{2}-\mathrm{NPs}$ in hydroponic solutions with different $\mathrm{N}$ sources. $\mathrm{Ce}-0=0 \mathrm{mg} \mathrm{CeO}{ }_{2}-\mathrm{NPs} / \mathrm{L}, \mathrm{Ce}-500=500 \mathrm{mg} \mathrm{CeO}_{2}-\mathrm{NPs} / \mathrm{L}$. Values are means \pm SE $(n=6)$. Statistical difference between Ce-0 and Ce-500 at $\mathrm{P} \leq 0.10,0.05$, and 0.01 between $\mathrm{Ce}-0$ and $\mathrm{Ce}-500$ treatments was indicated as *, $* *$, and $* * *$, respectively. 


\section{Wheat}
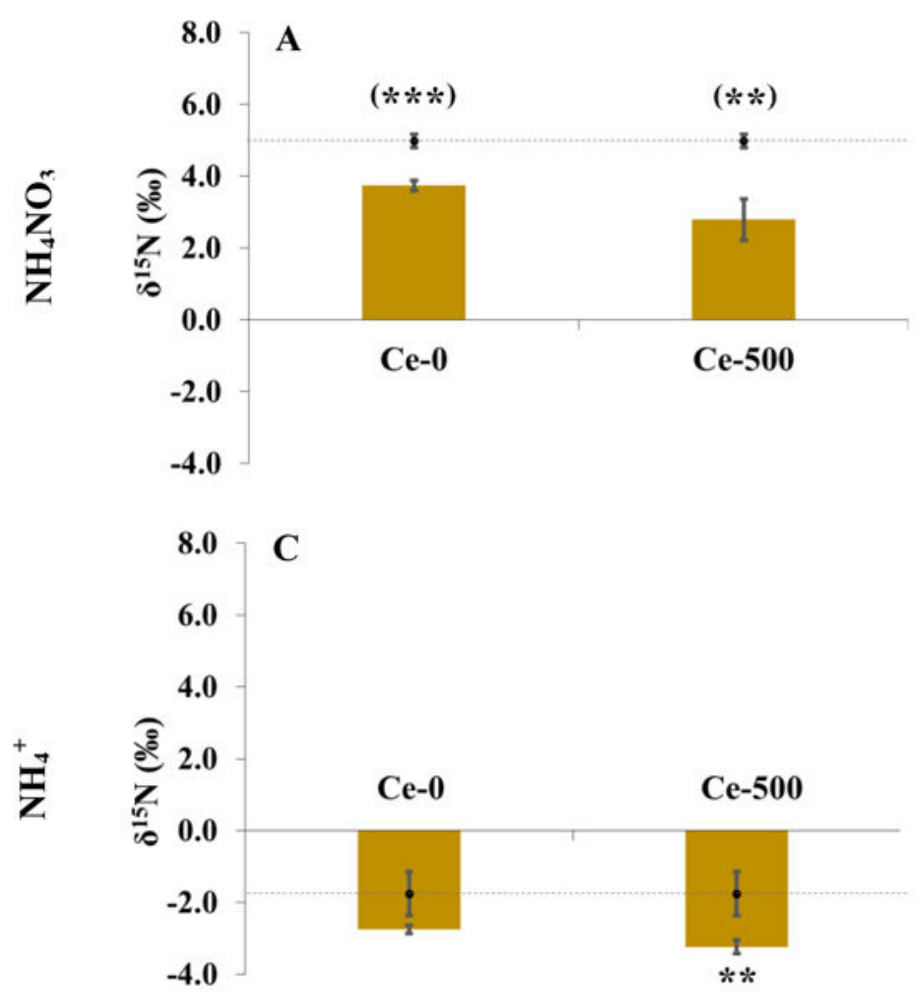

(*)

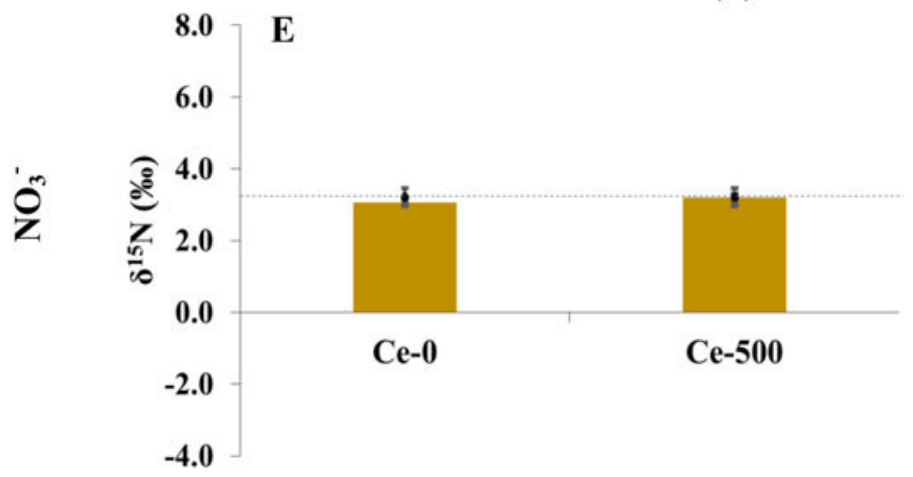

Barley
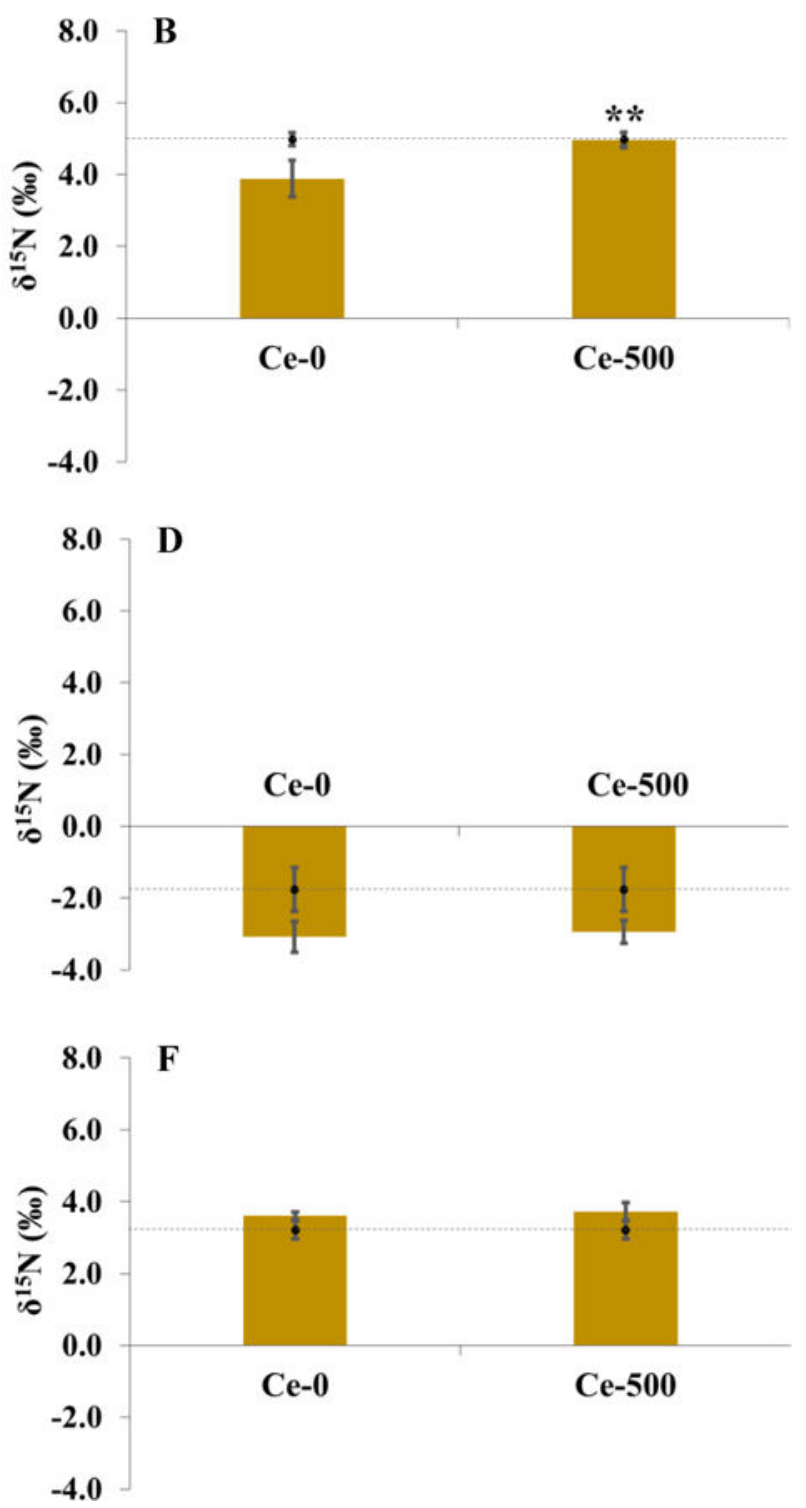

Figure 2.

Whole-plant $\delta^{15} \mathrm{~N}$ of wheat and barley exposed to $\mathrm{CeO}_{2}-\mathrm{NPs}$ in hydroponic solutions with different $\mathrm{N}$ sources. $\mathrm{Ce}-0=0 \mathrm{mg} \mathrm{CeO}-\mathrm{NPs} / \mathrm{L}, \mathrm{Ce}-500=500 \mathrm{mg} \mathrm{CeO}-\mathrm{NPs} / \mathrm{L}$. Values are means $\pm \mathrm{SE}(n=6)$. Statistical difference between Ce-0 and Ce-500 at $\mathrm{P} \leq 0.10,0.05$, and 0.01 between $\mathrm{Ce}-0$ and $\mathrm{Ce}-500$ treatments was indicated as *, **, and ***, respectively.

Labels outside the bar indicates differences in $\delta^{15} \mathrm{~N}$ between $\mathrm{CeO}_{2}-\mathrm{NPs}$ while in labels in parenthesis indicates differences in $\delta^{15} \mathrm{~N}$ between $\mathrm{CeO}_{2}-\mathrm{NPs}$ treatment and $\mathrm{N}$ source.

Dashed lines indicate the $\delta^{15} \mathrm{~N}$ of the $\mathrm{N}$ source. 
Wheat

Root
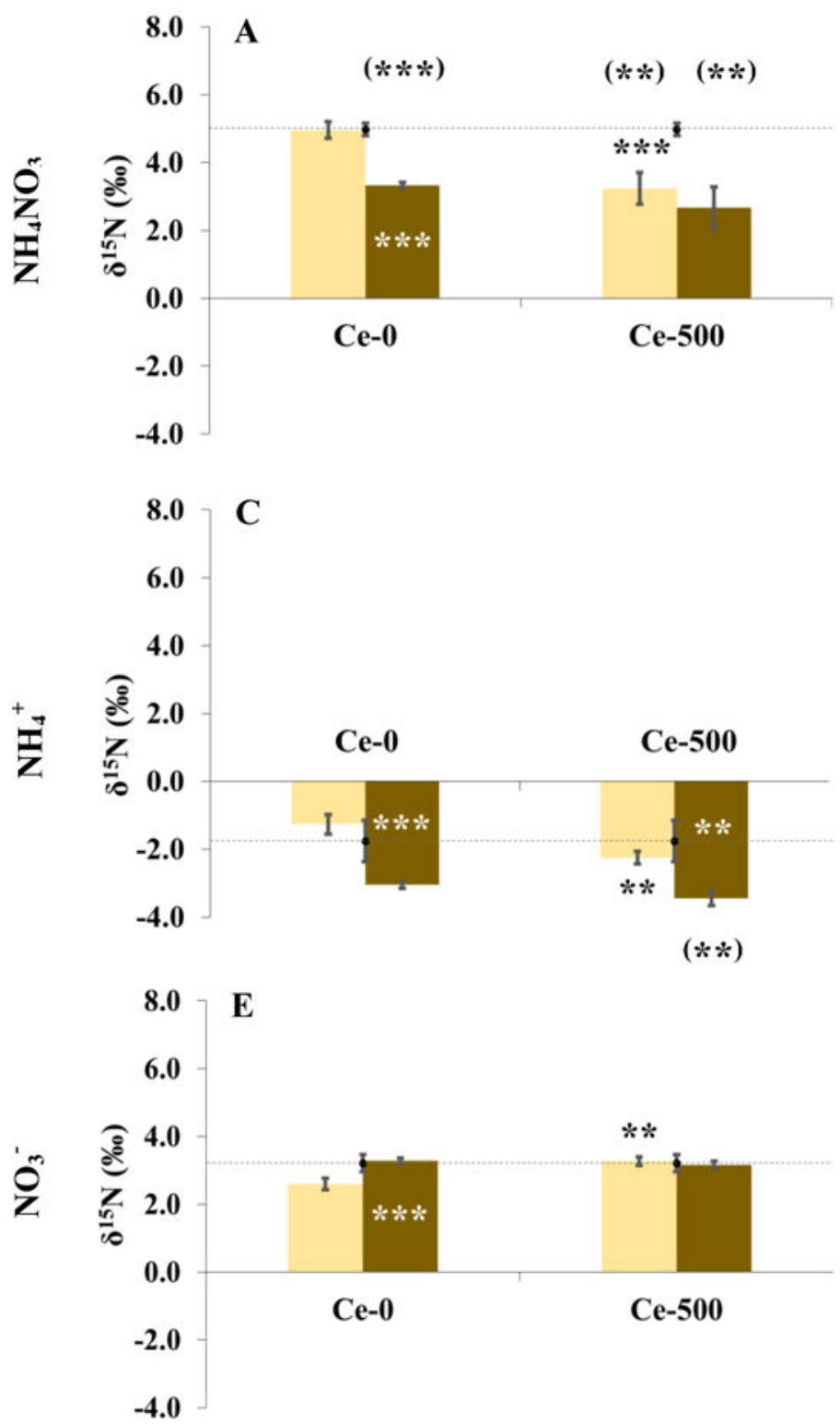

\section{Barley}

Root
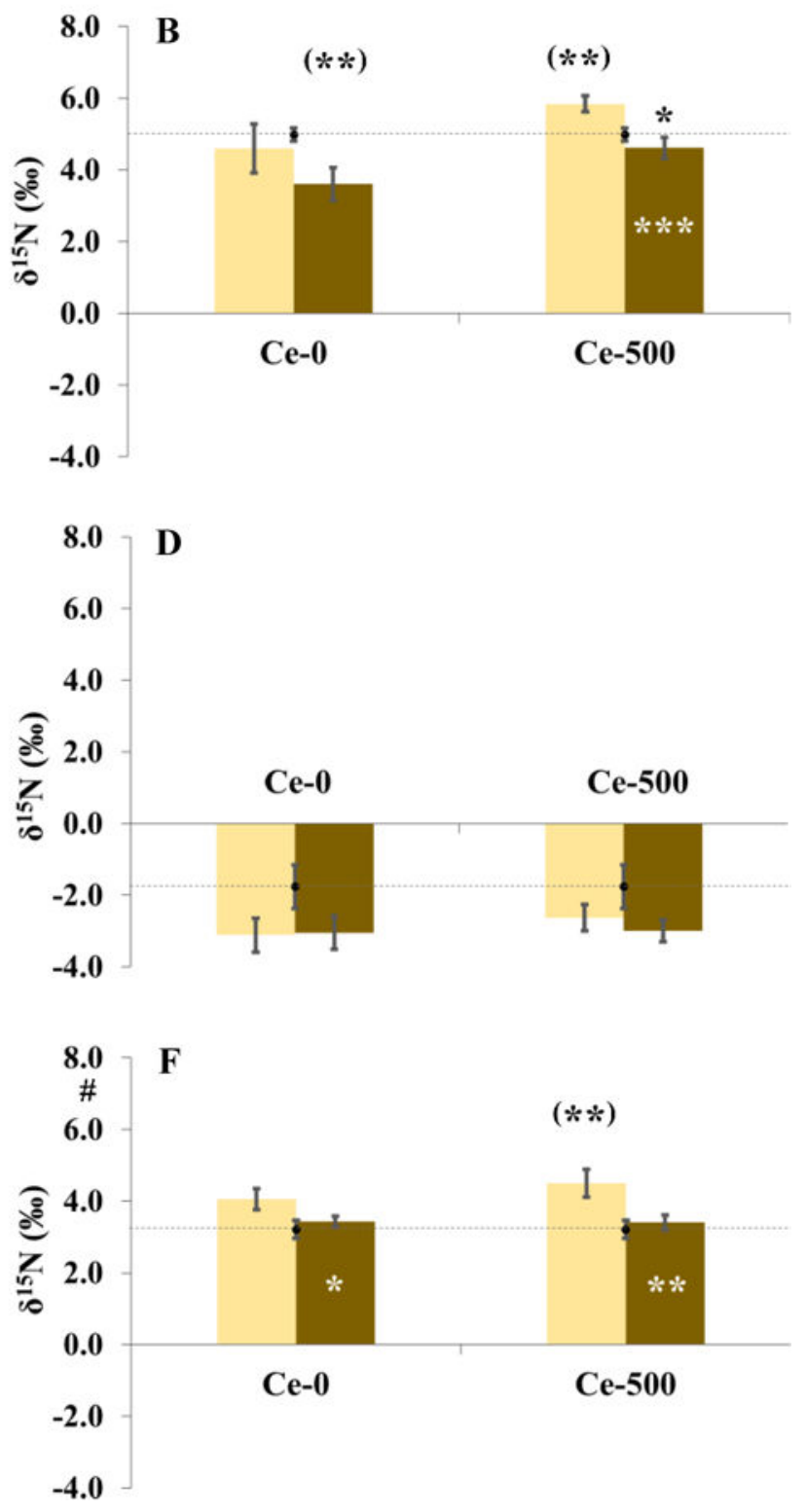

Figure 3.

Isotopic $\delta^{15} \mathrm{~N}$ of wheat and barley exposed to $\mathrm{CeO}_{2}-\mathrm{NPs}$ in hydroponic solutions with different $\mathrm{N}$ sources. $\mathrm{Ce}-0=0 \mathrm{mg} \mathrm{CeO}{ }_{2}-\mathrm{NPs} / \mathrm{L}, \mathrm{Ce}-500=500 \mathrm{mg} \mathrm{CeO}{ }_{2}-\mathrm{NPs} / \mathrm{L}$. Values are means $\pm \mathrm{SE}(n=6)$. Statistical difference between Ce- 0 and Ce-500 at $\mathrm{P} \leq 0.10,0.05$, and 0.01 was indicated as $*, * *$, and $* * *$, respectively. Labels outside the bar indicates differences in $\delta^{15} \mathrm{~N}$ between $\mathrm{CeO}_{2}$-NPs while in labels in parenthesis indicates differences in $\delta^{15} \mathrm{~N}$ between $\mathrm{CeO}_{2}-\mathrm{NPs}$ treatment and $\mathrm{N}$ source. Dashed lines indicate the $\delta^{15} \mathrm{~N}$ of the $\mathrm{N}$ source. 

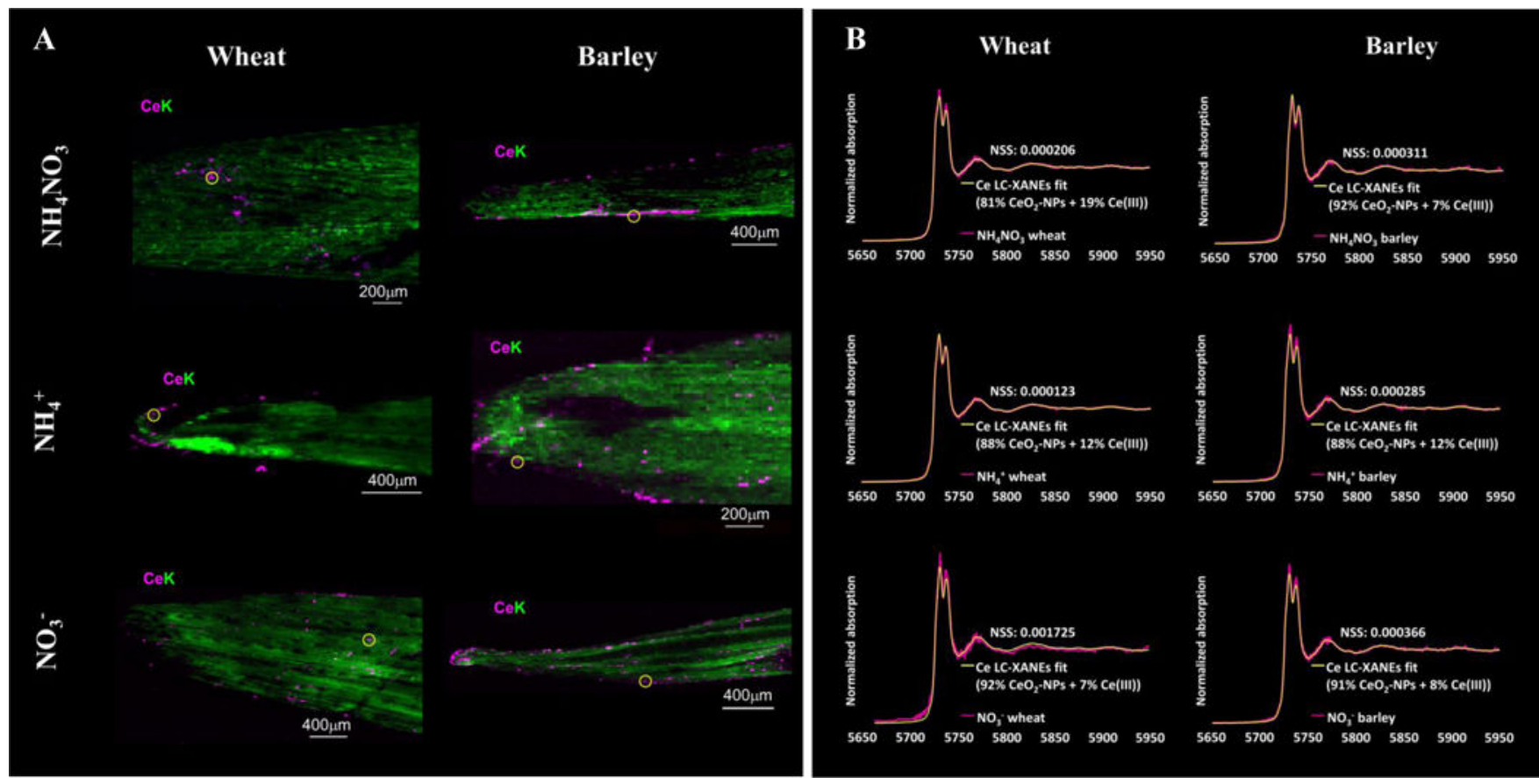

Figure 4.

Synchrotron micro-X-ray fluorescence analysis of wheat and barley exposed to $\mathrm{CeO}_{2}-\mathrm{NPs}$ at different $\mathrm{N}$ sources. (A) Bicolor micro-XRF maps of wheat and barley shoots (magenta $=$ $\mathrm{Ce}$, green $=\mathrm{K}$ ). (B) Ce micro-XANES spectra from spots on shoots. Spectra on magenta line represents linear combination fits and yellow solid line spectra represents $\mu$ XANES from the sample. The range of values in $\mathrm{Ce}(\mathrm{III})$ are from $\mathrm{Ce}(\mathrm{III})$ acetate, $\mathrm{Ce}(\mathrm{III})$ carbonate, $\mathrm{Ce}(\mathrm{III})$ oxalate, and Ce(III) phosphate. Exact values are given in Table D.1. 
Table 1.

Global mean (mean across different $\mathrm{N}$ sources) $\mathrm{N}$ and $\delta^{15} \mathrm{~N}$ of wheat and barley exposed to cerium oxide nanoparticles for 10 days in hydroponic suspension supplied with different forms of N. Values are mean \pm SE $(n=18){ }^{a}$

\begin{tabular}{lllll}
\hline Global mean & \multicolumn{3}{l}{ Wheat } & \multicolumn{3}{l}{ Barley } \\
\cline { 2 - 5 } & Ce-0 & Ce-500 & Ce-0 & Ce-500 \\
\hline Root biomass $(\mathrm{mg})$ & $45 \pm 7$ & $37 \pm 6^{* * *}$ & $23 \pm 4$ & $27 \pm 4$ \\
Shoot biomass $(\mathrm{mg})$ & $106 \pm 6$ & $96 \pm 5^{*}$ & $67 \pm 6$ & $76 \pm 6$ \\
Root $\mathrm{N}(\%)$ & $2.40 \pm 0.09$ & $2.43 \pm 0.07$ & $3.51 \pm 0.19$ & $3.09 \pm 0.14^{*}$ \\
Shoot $\mathrm{N}(\%)$ & $2.64 \pm 0.05$ & $2.58 \pm 0.09$ & $2.95 \pm 0.16$ & $3.09 \pm 0.14$ \\
Root $\mathrm{N}(\mu \mathrm{g})$ & $973 \pm 110$ & $842 \pm 113^{* *}$ & $743 \pm 96$ & $809 \pm 91$ \\
Shoot $\mathrm{N}(\mu \mathrm{g})$ & $2766 \pm 119$ & $2595 \pm 150^{*}$ & $1964 \pm 197$ & $2285 \pm 155^{* *}$ \\
Plant $\mathrm{N}(\mu \mathrm{g})$ & $3739 \pm 221$ & $3337 \pm 241^{* *}$ & $2707 \pm 287$ & $3094 \pm 235^{* *}$ \\
Root $\delta^{15} \mathrm{~N}(\% \circ)$ & $2.10 \pm 0.64$ & $1.42 \pm 0.65^{* * *}$ & $1.85 \pm 0.90$ & $2.57 \pm 0.92^{* *}$ \\
Shoot $\delta^{15} \mathrm{~N}(\% \circ)$ & $1.19 \pm 0.73$ & $0.80 \pm 0.76^{*}$ & $1.33 \pm 0.78$ & $1.68 \pm 0.82$ \\
Whole-plant $\delta^{15} \mathrm{~N}(\% \circ)$ & $1.35 \pm 0.71$ & $0.92 \pm 0.74^{*}$ & $1.47 \pm 0.81$ & $1.92 \pm 0.85$ \\
\hline
\end{tabular}

${ }^{a} \mathrm{Ce}-0$ and $\mathrm{Ce}-500$ were 0 and $500 \mathrm{mg} \mathrm{CeO} 2-\mathrm{NPs} / \mathrm{L}$. Statistical difference between $\mathrm{Ce}-0$ and Ce-500 at $\mathrm{P} \leq 0.10,0.05$, and 0.01 was indicated as *, **, and ${ }^{* * *}$, respectively. 
Table 2.

Biomass and $\mathrm{N}$ concentration of wheat and barley exposed to cerium oxide nanoparticles for 10 days in hydroponic suspension supplied with different forms of $\mathrm{N}$. Values are mean $\pm \mathrm{SE}(n=6)^{a}$

\begin{tabular}{lllll}
\hline & Wheat & \multicolumn{3}{c}{ Barley } \\
\hline & Ce-0 & Ce-500 & Ce-0 & Ce-500 \\
\hline $\mathbf{N H}_{\mathbf{4}} \mathbf{N O}_{\mathbf{3}}$ & & & & \\
Root biomass (mg) & $40 \pm 4$ & $22 \pm 3^{* * *}$ & $24 \pm 5$ & $29 \pm 2$ \\
Shoot biomass (mg) & $123 \pm 8$ & $95 \pm 12^{*}$ & $70 \pm 11$ & $83 \pm 10$ \\
Root N concentration (\%) & $2.51 \pm 0.08$ & $2.49 \pm 0.07$ & $3.80 \pm 0.31$ & $3.43 \pm 0.28$ \\
Shoot N concentration (\%) & $2.52 \pm 0.09$ & $2.20 \pm 0.17$ & $3.20 \pm 0.23$ & $3.36 \pm 0.28$ \\
\hline
\end{tabular}

\begin{tabular}{lllll}
$\mathrm{NH}_{\mathbf{4}}{ }^{+}$ & & & \\
Root biomass (mg) & $16 \pm 1$ & $18 \pm 2$ & $7 \pm 1$ & $10 \pm 1^{* * *}$ \\
Shoot biomass (mg) & $77 \pm 3$ & $86 \pm 4$ & $46 \pm 5$ & $55 \pm 5$ \\
Root N concentration (\%) & $2.74 \pm 0.02$ & $2.71 \pm 0.05$ & $3.38 \pm 0.22$ & $2.93 \pm 0.05^{*}$ \\
Shoot N concentration (\%) & $2.78 \pm 0.06$ & $2.81 \pm 0.07$ & $2.31 \pm 0.12$ & $2.75 \pm 0.16^{* *}$ \\
\hline $\mathrm{NO}_{\mathbf{3}^{-}}$ & & & & \\
Root biomass (mg) & $78 \pm 4$ & $71 \pm 3$ & $37 \pm 5$ & $41 \pm 4$ \\
Shoot biomass (mg) & $119 \pm 4$ & $108 \pm 5$ & $84 \pm 11$ & $89 \pm 11$ \\
Root N concentration (\%) & $1.93 \pm 0.07$ & $2.09 \pm 0.09$ & $3.35 \pm 0.43$ & $2.91 \pm 0.28$ \\
Shoot N concentration (\%) & $2.63 \pm 0.07$ & $2.72 \pm 0.06$ & $3.33 \pm 0.28$ & $3.16 \pm 0.24$ \\
\hline
\end{tabular}

${ }^{a} \mathrm{Ce}-0$ and $\mathrm{Ce}-500$ were 0 and $500 \mathrm{mg} \mathrm{CeO} 2-\mathrm{NPs} / \mathrm{L}$. Statistical difference between $\mathrm{Ce}-0$ and $\mathrm{Ce}-500$ at $\mathrm{P} \leq 0.10,0.05$, and 0.01 was indicated as *, **, and ${ }^{* * *}$, respectively. 